\title{
1. Introduction to the Handbook of Territorial Politics
}

Eve Hepburn and Klaus Detterbeck

\section{INTRODUCTION}

Imagine in your mind's eye a satellite image of the earth. You can probably see vast blue oceans and green-brown streaks of land that are half-hidden by swirls of white cloud. You might think: how beautiful, how whole, how solid is this earth of ours. How fortunate we are - the human race, some 7.4 billion people - to occupy such an abundant, though increasingly fragile, habitat. But then you might cast your memory back to an old atlas you saw when you were a child: how thick black lines sliced up the land into smaller pieces. You might reflect on how, if you take a closer look, humanity has always divided itself into self-contained communities. And that many of these communities do not exist anymoreclans and tribes, city-states and principalities, kingdoms and empires. Instead, our earth is currently divided into 195 countries - the vast majority of which are 'nation-states', a political form that emerged a mere 370 years ago with the creation of the Westphalian system in 1648 .

But as a student of territorial politics, you know that this system of nation-states is far from being perfect, or secure. Because you're aware that the territorial configuration of our modern world is being challenged on a near-constant basis, from above as well as below. You may know that, since 1941, we've seen the creation of 129 new nation-states (Baldacchino and Hepburn, 2013), and some 34 of those have been created since 1990. Some of those countries declared independence with the collapse of a vast political regime (the Union of Soviet Socialist Republics), some emerged from the dissolution of a former country (Yugoslavia), some merged together to form a single unit (Yemen), others gained sovereignty with the spread of de-colonization (Palau or the Marshall Islands), and others split in two (South Sudan from Sudan).

And if you have your eye on the news, and not just the history books, you're probably aware that this process of creating new nation-states is unlikely to end any time soon. Catalonia is - at the time of writing - in the midst of a political tug-of-war with the Spanish Government, having declared independence in a referendum declared unconstitutional by the Spanish Court. In Taiwan, the issue of maintaining relations with mainland China or pursuing independence has dominated domestic politics for decades. In Corsica, a newly elected nationalist alliance has just petitioned for greater autonomy from France. The question of Palestine independence lies at the heart of the Arab-Israeli conflict in the Middle East. In the UK, Scotland narrowly voted against a referendum in 2014, but its pro-independence government plans to hold another independence referendum in the future. And the list of political movements agitating for independence for their territories goes on - such as Quebec in Canada (which has already held two unsuccessful independence referenda), Puerto Rico in the USA (which has now held six referenda on its 
political/constitutional status, with the most recent in 2017 revealing a majority in favour of US statehood), Veneto in Italy (which held an unofficial independence referendum in 2014) and the Basque Country (whose proposed independence referendum in 2008 was deemed unconstitutional by the Spanish Court). And then there is the question of the European Union itself - can this innovative political experiment to bond sovereign nation-states together in the name of peace, security and common values survive the sledge-hammer of the UK exit (Brexit)?

The sweeping political changes to the modern system of states since the collapse of empire, in addition to the growing number of territorial movements seeking self-rule, indicates that our Westphalian system of sovereignty is in a constant process of flux. And that is the main reason why we have put together this Handbook of Territorial Politics. Because we know that territory has always - and will continue to - shape the social and political evolution of humanity. For we know that territory is not just some abstract geographical term, or the lines drawn on a map. Instead, as scholars of territorial politics, we know that our relationship with territory is about social and political community. It's about the sense of belonging that we need to survive, both individually and collectively. And that is why territory will never be fully 'ironed out' by the advance of the nation-state, and why - over the next few hundred years - we will continue to see the reconfiguration of territory to best meet our human needs.

\section{A RENAISSANCE IN THE STUDY OF TERRITORIAL POLITICS}

Given the territorial flux in the modern system of nation-states - with the creation of new states and the dissolution of others - it should not come as much surprise that the study of territorial politics has enjoyed something of a renaissance in the last thirty-odd years. Scholarship has emerged that takes territorial units other than the nation-state as the main focus of analysis - such as cantons, provinces and cross-border regions (Simeon, 1980; Rokkan and Urwin, 1983; Keating, 1988). Political geographers have analysed how 'territory' is a social construct and constantly being recreated (Agnew, 1987; Paasi, 2002). Legal theorists have been talking about 'shared sovereignty' and 'constitutional pluralism' (Walker, 2002; Mac Amhlaigh, 2017). Economists have pointed to locality and region as the most helpful unit for understanding economic development (Amin, 1999; Bagnasco and Le Galès, 2000). Social scientists have examined the institutional configurations of territorial political, economic and social systems (Swenden, 2006; Behnke and Benz, 2009; Bolleyer, 2009). And historians have sighed and reminded us: it was ever thus (Applegate, 1999). 'Territorial politics' is not a new idea. Territory, as an organizational principle for framing politics and society, as a 'spatial strategy to affect, influence, or control resources and people, by controlling area' (Sack, 1986, p. 19), has been shaping the evolution and development of human progress since time immemorial (see Moore, 2015).

But perhaps what makes the current period of scholarship unique is that students of territorial politics have made a concerted attempt to challenge the fundamental architecture upon which mainstream social science has been built: the all-encompassing narrative of the nation-state. Why? Because throughout the post-war period, scholars privileged the 'nation-state' as the only meaningful unit of analysis for political, social and economic life (see Keating in this volume). The modernizing paradigm of the nation-state was seen 
to 'level' any territorial differences within its borders, leading to the 'end of territory' as Badie (1995) once argued. Politics was said to be determined by social class interests that operated in a standardized fashion across states. And as a result, social scientists tended to neglect the role of territory in informing politics. Indeed, throughout the twentieth century, there was a strong tendency to overlook, undermine, or define 'territory' out of existence by labelling any form of territorial politics as an oddity. Territorial cleavages were treated as 'throw-backs' to the past according to Hobsbawm (1990), and territorial movements were 'revolts against modernity' as Lipset (1985) put it. In short, territory, regions and nationality questions were long portrayed as a setback for the modern state, whose main purpose was national integration and assimilation.

This has been an odd kind of academic ganging-up on the issue of territory in political systems. The view that the nation-state is the only meaningful unit of analysis in the study of social science, and indeed that it constitutes the 'end-point' of human history as Fukayama (1989) argued, has been long dominant. But some scholars - arguably on the 'periphery' of mainstream political science - began to marshal evidence to the contrary in the late twentieth century. And these scholars came from a variety of disciplinary backgrounds - political geography, political science, sociology, economics and history. The 'pioneers' of territorial politics - including Stein Rokkan, Charles Tilly, Michael Keating, John Agnew, Richard Simeon, Daniel Elazar, Jill Vickers, Luis Moreno, Arthur Benz, Lieven De Winter, Patrick Le Galès, Carol Weissert and many others who appear in this volume - argued that territory continues to be an essential fact of political life, evidenced in the decentralization of state structures, the rise of sub-state nationalist and regionalist parties, the representation of sub-state interests within and beyond the nation-state, and the territorial basis of identities, cultures and languages. Moreover, these scholars argued that the normative fixation with the nation-state could in fact be interpreted as a form of 'methodological nationalism' (Wimmer and Glick Schiller, 2002) - the intellectual advocacy of the virtues of the large, modern nation-state, which castigates smaller political communities that lie within them as anti-modern.

But there has been something of a revolution in the social sciences in the last thirty-odd years (Keating, 2008), as scholars of regionalism, federalism, nationalism and political geography have supplied empirical evidence, arguments and theories to make the case for an outright rejection of these state-centric views of politics. And these challenges to mainstream science have popped up throughout the world.

Perhaps the greatest challenge was mounted by scholars located in the European Union, who saw on a daily basis how the sovereignty of the nation-states they inhabited was being challenged from above by Europeanization and from below by regions that were being empowered by European opportunity structures. The European project was re-drawing scholarly conceptions of Westphalian sovereignty, creating opportunities for a number of self-determination movements to emerge. Challenges to mainstream science were also evolving in North America, where the history of federalism in Canada and the USA, in particular, gave scholars a more nuanced understanding of how territory shapes and contains social and political life. In Africa, de-colonization went hand-in-hand with territorial empowerment and self-determination, while in the Pacific, the independence of former island colonies catalysed a new inter-disciplinary field on 'island studies'. In East Asia, the management of territorial pluralism - signified by special status for Taiwan, Tibet and Hong Kong - was a source of constant strain for the Chinese government, while 
in South-East Asia, the federalization of India revealed how territorially, culturally and linguistically diverse this vast and complex country was. In Central and South America, the adoption of the federal model by larger countries such as Brazil, Argentina and Mexico was underpinned by processes of democratization, while indigenous movements for autonomy in Peru, Ecuador, Chile, Mexico, Colombia and elsewhere continued to demand their territorial rights and representation. And in the Middle East, the creation of federal structures in Iraq, Syria and Yemen has been underscored by conflict and the ongoing challenges of overcoming ethnic division.

While being vastly different, these cases from around the world all reveal that the 'nationalization' or 'modernization' of politics has run into problems; namely, the existence of distinctive territorial identities based on history, language, culture or institutional traditions. These territorial units have provided an alternative setting for defining the political and social community, and their very persistence marks a failure of nation-statebuilding processes. Instead, we are now seeing alternative projects of territorial autonomy within states, characterized by competition for resources and power. Does this mean that the nation-state is in fact a temporally limited entity, whose time is almost up? Perhaps not quite yet. However, it does mean that we need to acquire a more sophisticated conception of territory that encompasses different scales and units, to fully understand how human society wishes to organize itself.

\section{AN ONWARD DRIVE TOWARDS TERRITORIAL RESCALING?}

Students of territorial politics have been amassing a wealth of data and research on the continuing importance of territorial institutions and frames. And one of the most important pieces of evidence to have emerged is the growing trend towards decentralization and the 'territorial rescaling' - as Keating (2013) puts it - of the nation-state. This trend has largely been in response to territorial demands for the accommodation and recognition of smaller self-determining political communities. In liberal democracies in particular, many of the functions and powers of states have been transferred downwards towards the sub-state regional level. One group of scholars has provided us with a quantitative analysis of regional decentralization. Marks et al. (2008) created a 'regional authority index' that accounts for the main characteristics of regional authorities that exist across the world from 1950 to 2006. Their findings revealed that, of the 42 countries they examined, half of them had created regional tiers and no country had become more centralized. This trend is particularly marked in Europe, where all of the large Western European states - Germany, France, Spain, Austria and Italy - as well as some of the smaller ones, like Belgium and Switzerland, have created or strengthened regional tiers of authority. Indeed, since the 1970s, 19 European Union member states have introduced elections to a regional tier of government and shifted authority downwards. As a result, there are now 74 regions with legislative powers in Europe - a process of decentralization that has been fully supported by the European Union, as well as the World Bank and the Organisation for Economic Co-operation and Development (OECD). Although there has been no uniform pattern of decentralization across or within states, this process has led to the creation of new substate executives and parliaments with wide-ranging legislative competences, with control over large sections of policy, including health, education, housing, the environment, 
planning and economic development. As a result, the vast majority of large states in the world are characterized by considerable territorial diversity, and many of them have a multilevel or multinational form.

Why have states decentralized powers to the sub-state level? Here, we need to adopt a historical perspective, and it is helpful to begin by looking at Europe - perhaps the most concentrated system of territorial decentralization in the world. Since the end of the Second World War, states in Europe have to varying degrees pursued regional development policies in order to integrate poorer areas into the national economy. Regional development was motivated in part by the recognition that the macro-economic regulation of the market was being undermined by different economic conditions obtaining from region to region (Bullman, 1997). Central governments advanced spatial policies designed to overcome what was perceived as a temporary problem of regional disparities. Although sub-state regions were initially viewed as objects of state planning, in time central-planning staffs sought greater input from regional actors. This may have been motivated by the need of central governments to offload the cumbersome administrative apparatus of the state to lower sub-state levels. However, these top-down regional policies also contributed to the growth in bottom-up demands for greater territorial autonomy. Largely in response to regionalist demands, many European states abandoned their top-down regional development approaches in favour of creating legislative regional authorities. Economic efficiency became an insufficient argument to justify decentralization; instead it took on a strongly democratic and normative flavour as part of a regionalist revival.

For instance, from the late 1980s in particular, the empowerment of the sub-state regional level became widely viewed as a method for improving the functioning of democracy. Decentralization has been viewed as a way to improve the legitimacy and accountability of political institutions, the delivery of public services and policy innovation. In an age of decreasing levels of political trust and participation in political processes, regional autonomy has been offered as part of the solution, as it creates 'decision-making processes that are closer to the individuals, it takes into account cultural, social and economic specificities and identities, distributes public finances between more or less successful territorial entities and, ultimately, it enhances political participation of the entire society' (AER, 2012). This theory is linked to the concepts of political pluralism - which lies at the heart of liberal democracy and implies that power should be dispersed among a variety of groups - and subsidiarity - which means that decision-making should be taken at the lowest appropriate level. Brought together, decentralization is seen as a way to facilitate greater participation of citizens in regional decision-making and to recognize territorial distinctiveness.

Indeed, political pluralism has become - along with free elections and the protection of civil and human rights - a cornerstone of liberal democracy (Rawls, 1996). It implies that power should be dispersed among a variety of groups to avoid excessive centralization and domination by a single group. Thus, political pluralism involves the recognition of diversity, that is, the existence of multiple interests in society, which - if not managed may lead to intransigent conflict. In states with high levels of territorial diversity, the institutionalization of pluralism through decentralization to sub-state units is increasingly viewed as the best way to manage diversity without disrupting the territorial sovereignty of the state (Linz,1997). Pluralism and autonomy have therefore become centrally embedded characteristics of democracy. 
Another important normative argument in favour of territorial rescaling and decentralization involves the concept of subsidiarity. Subsidiarity implies that decision-making should be taken at the lowest, most appropriate, level possible. It is based on the idea that all that can optimally be done at the lowest level should be reserved to that level, while only residual powers - or tasks that lower levels are not in a position to do - should be passed to the higher levels (Hrbek, 2003; Loughlin, 2005). The goal is to restrain state power and to allow solutions to be achieved at a lower level. Policies are developed on a 'bottom-up' basis and tailored to the interests of the regional citizenry rather than being imposed 'from above'. Subsidiarity is seen as an important way of fostering greater direct participation of citizens in decision-making processes, thereby strengthening democracy. However, there are various conditions that need to be met in order to have a fully functioning democracy at the regional level. And perhaps the most important of these is the need for decentralization to have popular legitimacy - that is, that people should want devolution.

This brings us to regionalism and nationalism - the bottom-up demands for political decentralization coming from within the sub-state unit itself. And as scholars have revealed, political demands for self-determination have been on the rise for the last 40 years (De Winter et al., 2006; Hepburn, 2011). Sub-state nationalist and regionalist parties (SNRPs) have grown in size and strength, entering government at the regional and state level, forcing other parties to respond to their demands, and implementing their policy proposals (De Winter and Türsan, 1998; Elias and Tronconi, 2011; Hepburn, 2011). One could argue that these territorial movements have challenged the very existence of the nation-states in which they were embedded, by demanding various forms of autonomy ranging from decentralization to independence and effecting territorial reform (Toubeau and Massetti, 2013). But these movements are by no means homogeneous. An analysis of SNRPs reveals that they span a variety of ideological positions on the left-right spectrum, ranging from socialism to radical-right populism, with social democrats, liberal-centrists and Christian democrats between these extremes (Elias, 2011; Hepburn, 2011). It is also clear that regionalism is not necessarily secessionist (see Massetti and Schakel, 2013). Many regionalisms are 'integrative' in that they see no tension between region-building and nation-building strategies, and seek to integrate themselves further into the public life and economy of the nation-state. However, the accommodation of self-determination within states is potentially just as constitutionally disruptive to the concept of the 'unitary state' as independence would be. This is especially true as SNRPs often influence the positions of mainstream parties, encouraging them to adopt stronger territorial demands (Detterbeck and Hepburn, 2010; Detterbeck, 2012; see Hepburn in this volume). Which means that these territorial movements - and the decentralization and territorial rescaling they have engendered - have changed the face of modern democracies.

\section{THE AIMS AND STRUCTURE OF THIS HANDBOOK}

The aim of this Handbook is to provide the reader with a single volume that brings together the most cutting-edge research on territorial politics from across the world, and to set out new research agendas for the future. Scholars of territorial politics - which span the fields of regionalism, federalism, nationalism, intergovernmental relations, 
public policy, comparative politics and multilevel governance - have together supplied empirical evidence, theories and arguments to make the case for an outright rejection of state-centric views of politics. Instead our contributors convincingly argue that we need to understand how and why territory continues to provide a source of belonging, identity, social values, political life and economic development within and across the borders of nation-states.

As territorial politics is a truly inter-disciplinary subject, we have invited scholars from the fields of political science, sociology, public policy, political geography, international relations, history, law and economics to present the state of the art in their field, and to comment on what they see as the most significant areas of research that we need to tackle. Each of our contributors have their eyes not only on the past and/or present, but also the future trajectories of territorial politics. Furthermore, as the study of territorial politics is a global phenomenon, we have invited senior and early-career scholars from around the world to scrutinize and compare developments in their countries. The subsequent chapters highlight the interplay of diverse factors in the development of territorial institutions and ideas, the idiosyncratic nature of territorial change in each country, and patterns of territorial mobilization and rescaling across countries. The Handbook is furthermore divided into four parts, to orient the readers to different sub-topics and themes. These are: (1) Institutions, Actors and Ideas; (2) Elections, Parties and Political Culture; (3) Territorial Public Policies; and (4) Geographical Perspectives. The result - we hope - is a comprehensive and international compendium on the latest research in key areas of territorial politics, which we hope will be of value for years to come.

\section{Institutions, Actors and Ideas}

Part I of the Handbook focuses on the concepts, theories and empirical developments within the study of territorial politics. Here, we are interested in the ideas and ideologies driving territorial change, the institutional division of power, and the political actors effecting constitutional and policy change. In Chapter 2, Michael Keating traces the development of the discipline of territorial politics. Adopting a constructivist and political perspective, he theorizes how territorial politics - far from disappearing with the advance of the modern nation-state - has instead become more important in recent decades. He argues, though, that this has not produced a new and definitive spatial order but, rather, a rescaling of different economic, social and political systems above and below the state. Moreover, it is important to understand territory not as a fixed, topological concept, but rather as a more open-ended and sociological concept, that has multiple meanings and forms.

In Chapter 3, Nathalie Behnke provides us with an overview of the territorial architecture of power. Despite criticisms of the Westphalian system, she argues that the organization of power is still bound to the boundaries of 'states' as subjects in international law. This means that states need to ensure that their power is accepted and distributed across the territory. She suggests that we use the concept of 'multilevel government' to understand how power is allocated horizontally and vertically across states, which also allows us to make systematic cross-territorial comparisons that enable us to build theoretical propositions. For while there is no single best way to organize power in the territory, we can identify structural patterns that promote transparency, dialogue and compromise. In 
Chapter 4, Nicole Bolleyer explores the challenges of interdependence and coordination in federal systems. Interdependence is a core feature of federal regimes, which is separate from decentralization, and it creates intense pressures for coordination. The way in which federal systems combine degrees of interdependence and decentralization varies considerably. Bolleyer provides a systematic analysis of possible modes of coordination that government units might adopt, examining the cases of Canada, the USA and Switzerland in greater detail.

Chapter 5 focuses on the theoretical, normative and empirical aspects of multilevel governance with a special emphasis on territorial politics. Simona Piattoni argues that the theoretical and definitional space of the concept of multilevel governance is threedimensional, interlinking state restructuring (polity), political mobilization (politics) and policy making (policy). She discusses the conceptual genealogy of multilevel governance to debunk some of the most extreme positions in the debate. Piattoni then discusses how political mobilization - catalysed by policy decisions triggered by global forces - is the aspect of multilevel governance that requires further research. Chapter 6 devolves into the issue of 'gendering' territorial politics. Jill Vickers considers the salience of gender for territorial politics, territory's importance for women's politics and how the modernist paradigm has undercut their use. She begins by examining how 'federal arrangements' (institutions, practices, discourses) are experienced differently by men and women, majority- and minority-culture women and over time. She also considers how legal pluralism affects women's rights and citizenship, and theorizes potential causal relations between state architectures and gender regimes. Finally, Vickers identifies conditions under which power hierarchies are restructured through decentralization or devolution, making the re-gendering of 'federal arrangements' possible.

The final chapter in Part I concentrates on the increasing use of decentralization as a tool of conflict resolution. Chapter 7 by Soeren Keil and Paul Anderson highlights how different forms of decentralization have been used in order to bring warring parties together, provide autonomy for certain groups, and ensure a fair distribution of resources. While the logic behind using decentralization as a conflict resolution tool might seem obvious, it is not without its challenges. In particular, Keil and Anderson point to evidence from numerous case studies that suggests that decentralization mainly works if connected to other forms of power-sharing such as grand coalitions and minority veto rights. In addition, decentralization might lay the foundation for further calls for autonomy and independence.

\section{Elections, Parties and Political Culture}

Part II of this Handbook focuses on the ways in which territory has provided a basis for political mobilization, electoral competition, and identity and citizenship. The opening chapter explores how elections have been 'de-nationalized' with the creation of regional tiers of authority. In Chapter 8, Arjan Schakel traces how the idea of 'nationalization' of elections - which indicates a situation where parties compete across the statewide territory and win equally sized vote shares - no longer pertains in multilevel states. The inclusion of regional elections induces scholars to study the linkage or spillover between national and regional electoral arenas. Schakel argues that denationalization should be studied in a multilevel electoral context, which involves studying dynamic and static nationalization 
for parties and regions in both regional and national elections, as well as examining electoral spillovers.

Chapter 9 by Klaus Detterbeck and Eve Hepburn moves on to the study of political parties themselves, and how they have been transformed by territorial politics. Parties were once considered to be the main instruments of national integration across states, however territorial rescaling has forced statewide parties to adapt to the new realities of multilevel governance, both organizationally and programmatically. This is especially important when statewide parties are competing with a strong nationalist or regionalist party, whose goals for self-determination have won substantial support. Detterbeck and Hepburn explore the conditions under which a 'territorial rescaling' of party politics occurs, providing an analytical framework of multilevel party politics that is valid for Western and Eastern Europe (and beyond).

Continuing the focus on political actors, Chapter 10 by Lieven De Winter, Marga Gomez and Peter Lynch focuses specifically on ethno-regionalist parties, with the aim of addressing the most pressing concerns regarding the state of this party family. While the map of autonomist parties has remained relatively stable over the past decade, new issues have attracted academic attention, such as: To what extent can we identify a general stability or decline in the success of these parties? And, to what extent can we identify a pattern of continuity or change in the nature of territorial demands, such as independence? De Winter, Gomez and Lynch examine the political strategies and political opportunity structures of autonomist parties and the new dilemmas and trade-offs they confront, both at the regional and European level.

To wrap up Part II on political mobilization, Chapter 11 by Eve Hepburn constructs a theoretical framework for understanding the 'territorial contagion' effect of sub-state nationalist and regionalist parties (SNRPs) on statewide parties. She argues that SNRPs can exert a formidable influence on the territorial positions of other parties, encouraging them to more strongly defend territorial interests and pursue enhanced forms of self-determination, and to decentralize party structures. Hepburn's theoretical framework on 'territorial contagion' contains a number of hypotheses, including: that contagion has a stronger impact on centre-left parties than on centre-right parties, that it works mainly at the sub-state level, that it affects parties in government more than those in opposition, and that it has more apparent effects on programmatic discourses than on organizational adaptation.

In Chapter 12, Klaus Stolz narrows the unit of political analysis further by exploring the relationship between territorial politics and political careers. He begins by mapping out the territorial dimension of political careers, revealing how opportunity structures for professional politicians contain the potential for multiple movements within and across various territorial levels of government. These movements can be condensed into a typology of four distinctive career patterns: the classical springboard pattern, the inverse springboard pattern, a pattern of non-hierarchical integration and a pattern of alternative careers. Stolz then shows how individual political careers and collective career patterns may influence and condition the conduct of institutional and territorial politics. He reveals how political careers and territorial politics are strongly intertwined, and makes a call for future research to develop analytical frameworks and conceptual tools to capture these relationships.

In Chapter 13, Luis Moreno moves the unit of analysis from parties to people, as he explores how citizens develop multiple territorial identities when they live inside multilevel 
polities. Moreno begins with the concept of citizenship, exploring how this is a compound of collective attachments and a product of nested identities formed at the various contextual levels of citizens' political attachments (supra-state, state, sub-state). Citizenship is a source for articulating political life in contemporary societies, and he argues that the revival of multiple ethnoterritorial identities can be regarded both as an increasing challenge to the centralist model of the unitary state and as a quest for the wider legitimating of territorial political institutions.

Complementing the discussion of identities, Chapter 14 by Lorenzo Piccoli focuses on how we may conceptualize regional citizenship in a system of plural memberships and multilevel rights. His research reveals that sub-state territorial rights and memberships are often entangled with national and supra-national regimes, producing complex architectures of citizenship. In this context, individual rights depend less on static national regimes and more on the interaction between institutions situated on a variety of territorial levels. Piccoli argues that, in a world in which boundaries are more open and a variety of political actors compete for power, regional polities are crucial actors in the construction of citizenship architectures.

\section{Territorial Public Policies}

Part III of this Handbook focuses on a variety of public policy areas that have been shaped by territorial politics. It begins, with Chapter 15, by focusing on education policy. Sandra Vergari explores whether elementary and secondary education policy in Canada and the USA is being 'dispersed' away from central governments or whether hierarchical modes of governance remain. She focuses on the extent to which education policy is decentralized, diverse, centralized, and homogeneous, and identifies the factors - local, national, global - that influence education policy. Chapter 16 moves the focus to health policy. Here, Scott Greer argues for the usefulness of health as a source of data for a more grounded and policy-focused territorial politics. He provides an overview of the health policy approach to territorial politics, arguing that its empirical findings, more than its theories, can enrich political science on the topic. He then examines the findings of political scientists, highlighting the extent to which comparative welfare state literature is sceptical about federalism, and the extent to which the literature about federalism and health is mostly nationally specific and overrepresents North American experiences. Greer concludes by recommending some potential future directions for research.

The focus of Chapter 17 is on environmental policy. Sonja Wälti reviews the theories, arguments and empirical evidence on how territorial forces shape environmental policies. While common approaches, including comparative environmental federalism, economic federalism, and policy diffusion and convergence, stress that territory shapes environmental policies, they fail to explain how - which is why an actor-centred approach is important. Wälti fills the gap by focusing on three types of actors - political parties, interest groups and federal jurisdictions - and by exploring their role in two policy areas: climate change and resource management. She finds that different actors play different strategic roles in environmental policy areas. Chapter 18 by Ilke Adam moves our focus to immigration policy, and the increased interest in this policy area from scholars of territorial politics. Adam provides a meta-analysis of cutting-edge research in this area, by examining research on the responses of sub-state actors to immigration in multilevel 
states, and by evaluating typologies and theoretical frameworks that seek to explain patterns of policy and party political divergence and convergence across sub-state regions.

In Chapter 19, Michaël Tatham explores the foreign policy of sub-state territories, which is known in the field as 'paradiplomacy'. He examines how sub-state regions, empowered by legislative competences, have sought to expand their territorial scope of action beyond their embedding state. While regions in federal systems have long played a role in the international relations, regions in other decentralized states have also become active across state borders. Tatham discusses the rise of regional paradiplomacy, outlining how regional actorness has developed over time and across levels of government, from the sub-national to the supra-national level. He also highlights the main determinants of regional paradiplomacy to understand why regions mobilize supra-nationally, and how this mobilization unfolds. Daniel Béland and André Lecours then move our focus to fiscal federalism in Chapter 20. They seek to examine why fiscal federalism can become a contentious political question and is the subject of intergovernmental conflict. Béland and Lecours draw primarily on the cases of Canada and Australia to investigate these questions. They examine the factors that contribute to the politicization of fiscal transfers and redistribution; vertical fiscal transfers and their potential for politicization; and the politics of horizontal fiscal redistribution. The authors conclude by tackling the questions of why these equalization programmes do not exist in the federal system of the USA.

In Chapter 21, John Agnew and Agostino Mantegna draw our attention to the relationship between territorial politics and economic development. They focus on four major strands of research. The first makes a case for the overall connection between politics, governance and economic development both in macro and micro settings. The second focuses on the important mediating role performed by local politicians in linking together political centres and their peripheries. The third is that which posits a strong direct connection between place-specific political histories and economic development. Finally, globalization and the spread of supra-national institutions have reoriented the geographic framing of territorial politics and its relationship to economic development. The chapter argues that studying economic development today requires careful attention to the emerging multi-scale politics.

In Chapter 22 César Colino explores the constitutional policies of territorial reform in federal and multilevel systems. He begins by defining and operationalizing the dimensions of territorial reform as a policy area, before examining several factors that account for its occurrence, contents and decision outcomes. Colino then presents an explanatory model, seeking to establish causal mechanisms and hypotheses. Unlike the usual perspective on change in federal systems that looks at evolution and long-term development, his perspective considers change from a short-term perspective and understands it as an intentional policy designed and adopted by governments and parliaments. Colino concludes with some reflections on the usefulness of the model and the relative importance of the different groups of explanatory factors.

\section{Geographical Perspectives}

Part IV of the Handbook seeks to step back from the detailed themes and issues that have emerged in the field of territorial politics by taking a wider geographical perspective. In particular, this part is interested in what concepts, methodologies and debates are of the 
greatest important in different parts of the world, and how might the study of territorial politics vary across place? Chapter 23 by Carol Weissert and Kevin Fahey focus on variation in approaches to territorial politics in Europe and the USA. While US scholarship focuses on institutional approaches, and European scholars typically pursue a more actor-centred approach, there is growing evidence of a convergence in recent federalism scholarship. Weissert and Fahey argue that while US scholars are increasingly paying attention to actors, European scholars are looking to institutions. They analyse this convergence by focusing on several key areas of federalism scholarship including political parties, intergovernmental bargaining, intergovernmental relationships and fiscal federalism.

In Chapter 24, Jan Erk focuses on comparative territorial politics in sub-Saharan Africa. He argues that, given that the territorial politics literature tends to place disproportionate emphasis on the experience of the western world, an unintended consequence is the relegation of the shared scope conditions to the background - such as the impact of high levels of political, economic, and technological development, and state capacity. Furthermore, case studies from the developing world are often reduced to a few institutional variables and national averages which conceal substantial within-case variation. His analysis of territorial politics in Africa exposes how uncodified and extra-institutional structural factors often influence the workings of federalism and decentralization, and how history still conditions the present.

In Chapter 25, Wilfried Swenden shifts our geographical perspective to South Asia. He maintains that the states of South Asia have not adopted uniform strategies in how they manage territorial divisions. This is especially true for the cases of India and Pakistan, despite the fact that they both used the Government of British India Act (1937) as their interim constitutions after Partition. Swenden examines how India has sought to manage territorial cleavages, before comparing this with Pakistan and Sri Lanka. He finds that each of these states has found it difficult to navigate between the accommodation of plurinational difference and the association of the state with a majority group; be it the Hindus in India (or Nepal), the Sinhala Buddhists in Sri Lanka or the Punjabis in Pakistan. Hence, while territorial self-rule is recognized as necessary for the implementation and making of policies in often large and complex polities, conceding such autonomy to accommodate plurinational difference has been more problematic. Finally, in Chapter 26 Nicholas Aroney and Campbell Sharman examine territorial politics and federalism in Australia. They maintain that Australian politics is organized in profoundly territorial terms, due to the essential role played by the constituent states within the Australian federal system. The constitution entrenched their role and - despite important tendencies towards centralization - the Australian states cannot be easily abolished or sidelined. Australia's party system reflects and reinforces the existence of a politics which is both national and regional in its dimensions. Moreover, the diversity between Australia's states, regions, cities and towns underscores the need for the kind of policy diversity and policy responsiveness that the Australian federal system makes possible.

\section{CONCLUSION}

Territorial politics constitutes nothing less than a revolution in social science and we hope that this Handbook will provide the reader with a compelling compendium on territorial 
politics that is of value for years to come. We have brought together leading and emerging scholars from across the world to demonstrate how territory has had an impact on institutional structures, public policies, elections and political parties, political culture, identity and citizenship in Europe, North America, Africa, Asia, Australasia and the Middle East, through innovative and original contributions that span comparative, theoretical and empirical research. The chapters in the Handbook challenge the dominance of state-centric perspectives and question the tendency in social science to correlate the boundaries of the 'state' with those of a 'nation'. Instead, our contributors have shone a light on the small worlds nested within, or stretching across, state boundaries. And they are not alone in doing so.

The nuanced conceptualization of the organization of political space, which ripples through this Handbook, is growing in prominence as more research is published on territorial politics, more university courses are being taught on regionalism, federalism and multilevel governance, and more events are being held on these topics. While the study of territorial politics was very much a 'niche' area when it first emerged in the 1960s and 1970s, we are moving towards a position where it is becoming part of the narrative in mainstream political science, reflected, for example, in the fact that we were invited to create this Handbook in the first place. This is no small accomplishment. We are grateful to all of the scholars who have advanced our understanding of how our social and political world is organized on a territorial basis that does not necessarily gel with state boundaries, and we dedicate this Handbook to them. But we also dedicate this Handbook to our students who have taught us so much, and to future generations of scholars of territorial politics. Nurture your compassion, your curiosity, your community, and your passion in speaking truth to (state-centric) power. Because we need your voices in this story.

\section{REFERENCES}

AER (Assembly of European Regions) (2012), 'Regionalisation and democracy: it's high time we placed the citizen back at the heart of governance', Assembly of European Regions Press Release, Brussels, 10 October.

Agnew, J. (1987), Place and Politics: The Geographical Mediation of State and Society, Boston, MA: Allen and Unwin.

Amin, A. (1999), 'An institutionalist perspective on regional economic development', International Journal of Urban and Regional Research, 23(2), 365-78.

Applegate, C. (1999), 'A Europe of regions: reflections on the historiography of sub-national places in modern times', American Historical Review, 104(4), 1157-82.

Badie, B. (1995), La fin des territoires, Paris: Fayard.

Bagnasco, A. and P. Le Galès (2000), Cities in Contemporary Europe, Cambridge: Cambridge University Press.

Baldacchino, G. and E. Hepburn (2013), 'A different appetite for sovereignty? Independence movements in subnational island jurisdictions', in G. Baldacchino and E. Hepburn (eds), Independence Movements in Subnational Island Jurisdictions, London and New York: Routledge, pp. 161-74.

Behnke, N. and A. Benz (2009), 'The politics of constitutional change between reform and evolution', Publius: The Journal of Federalism, 39(2), 213-40.

Bolleyer, N. (2009), Intergovernmental Cooperation - Rational Choices in Federal Systems and Beyond, Oxford: Oxford University Press.

Bullman, U. (1997), 'The politics of the third level', in C. Jeffery (ed.), The Regional Dimension of the European Union. Towards a Third Level in Europe?, London and Portland, OR: Frank Cass, pp. 3-19.

De Winter, L. and H. Türsan (1998), Regionalist Parties in Western Europe, London and New York: Routledge.

De Winter, L., M. Gómez-Reino and P. Lynch (eds) (2006), Autonomist Parties in Europe: Identity Politics and the Revival of the Territorial Cleavage, Barcelona: Institut de Ciències Polítiques i Socials.

Detterbeck, K. (2012), Multi-level Party Politics in Western Europe, Basingstoke: Palgrave Macmillan. 


\section{Handbook of territorial politics}

Detterbeck, K. and E. Hepburn (2010), 'Party politics in multi-level systems: party responses to new challenges in European democracies', in W. Swenden and J. Erk (eds), New Directions in Federalism Research, London and New York: Routledge, pp. 106-25.

Elias, A. (2011), Minority Nationalist Parties and European Integration: A Comparative Study, London and New York: Routledge.

Elias, A. and F. Tronconi (2011), 'From protest to power: autonomist parties in government', Party Politics, 17(4), 505-24.

Fukayama, F. (1989), 'The end of history', The National Interest, Summer.

Hepburn, E. (ed.) (2011), New Challenges for Stateless Nationalist and Regionalist Parties, London and New York: Routledge.

Hobsbawm, E. (1990), Nations and Nationalism since 1780, 2nd edn., Cambridge: Cambridge University Press.

Hrbek, R. (2003), 'The role of the regions in the EU and the Principle of Subsidiarity', The International Spectator: Italian Journal of International Affairs, 38(2), 59-73.

Keating, M. (1988), State and Regional Nationalism: Territorial Politics and the European State, Hemel Hempstead: Harvester Wheatsheaf.

Keating, M. (2008), 'Thirty years of territorial politics', West European Politics, 31(1-2), 60-81.

Keating, M. (2013), Rescaling the European State: The Making of Territory and the Rise of the Meso, Oxford: Oxford University Press.

Linz, J. (1997), Democracy, Multinationalism and Federalism, Madrid: Instituto Juan March de Estudios e Investigaciones.

Lipset, S.M. (1985), 'The revolt against modernity', in S.M. Lipset (ed.), Consensus and Conflict: Essays in Political Sociology, New Brunswick, NJ: Transaction Publishers, pp. 253-94.

Loughlin, J. (2005), 'The regional question, subsidiarity and the future of Europe', in K. Nicolaidis and S. Weatherill (eds), Whose Europe? National Models and the Constitution of the European Union, European Studies in Oxford: Oxford University Press, pp. 74-85.

Mac Amhlaigh, C. (2017), 'Pluralising constitutional pluralism', in N. Roughan and A. Halpin (eds), In Pursuit of Pluralist Jurisprudence, Cambridge: Cambridge University Press, pp. 64-89.

Marks, G., L. Hooghe and A. Schakel (2008), 'Measuring regional authority', Regional \& Federal Studies, 18(2), 111-21.

Massetti, E. and A. Schakel (2013), 'Between autonomy and secession: decentralization and regionalist party ideological radicalism', Party Politics, 22(1), 59-79.

Moore, M. (2015), A Political Theory of Territory, Oxford: Oxford University Press.

Paasi, A. (2002), 'Place and region: regional worlds and words', Progress in Human Geography, 26(6), 802-11.

Rawls, J. (1996), Political Liberalism, New York: Columbia University Press.

Rokkan, S. and D. Urwin (1983), Economy, Territory, Identity. Politics of West European Peripheries, London: Sage Publications.

Sack, D. (1986), Human Territoriality: Its Theory and History, Cambridge: Cambridge University Press.

Simeon, R. (1980), 'Intergovernmental relations and challenges to Canadian federalism', Canadian Public Administration, 23(1), 14-32.

Swenden, W. (2006), Federalism and Regionalism in Western Europe: A Comparative and Thematic Analysis, Basingstoke: Palgrave Macmillan.

Toubeau, S. and E. Massetti (2013), 'The party politics of territorial reforms in Europe', West European Politics, 36(2), 297-316.

Walker, N. (2002), 'The idea of constitutional pluralism', Modern Law Review, 65(3), 317-59.

Wimmer, A. and N. Glick Schiller (2002), 'Methodological nationalism and beyond: nation-state building, migration and the social sciences', Global Networks: A Journal of Transnational Politics, 2(4), 301-34. 